\title{
Representation of Ethiopian Wet Spells in Global and Nested Models
}

\author{
Mark R. Jury ${ }^{1,2}$ and Sen Chiao ${ }^{3}$ \\ ${ }^{1}$ University of Zululand, KwaDlangezwa, Richards Bay 3886, South Africa \\ ${ }^{2}$ Physics Department, University of Puerto Rico, Mayagüez, PR 00681, USA \\ ${ }^{3}$ Department of Meteorology and Climate Science, San José State University, San José, CA 95192, USA
}

Correspondence should be addressed to Mark R. Jury; mark.jury@upr.edu

Received 23 October 2013; Revised 11 January 2014; Accepted 13 January 2014; Published 5 March 2014

Academic Editor: Luis Gimeno

Copyright (C) 2014 M. R. Jury and S. Chiao. This is an open access article distributed under the Creative Commons Attribution License, which permits unrestricted use, distribution, and reproduction in any medium, provided the original work is properly cited.

\begin{abstract}
Weather forecast and reanalysis models exhibit different performance in daily rainfall estimation over the Ethiopian highlands, 2000-2012, with ECMWF closer to observations than other models. Background is given to illustrate the Hadley circulation and easterly jets over Ethiopia, using sections on $37^{\circ} \mathrm{E}$ in July-August 2011. ECMWF reanalysis has a narrow band of rainfall $>15 \mathrm{~mm} /$ day on $10^{\circ} \mathrm{N}$, consistent with TRMM satellite estimates, associated with a steep gradient in meridional wind. MERRA and GFS models have a wider band of rainfall and weaker gradients in meridional winds. The contrasting background states influence a nested WRF model simulation of heavy rain in the upper Nile Valley on 29 July, 2011. The GFS (ECMWF) initialization yields stronger northerly (southerly) winds north (south) of Ethiopia, while aircraft observations are southerly at $850 \mathrm{mb}$ and northerly at $700 \mathrm{mb}$. ECMWF produces heavy and widespread rainfall consistent with observations, with a potentially more realistic simulation of the Hadley circulation.
\end{abstract}

\section{Introduction}

Recent floods across Africa have restored water resources and improved crop yields, but also disrupted millions of lives [1-3]. Seasonal runoff $\sim 50 \cdot 10^{9} \mathrm{~m}^{3} / \mathrm{yr}$ from the Ethiopian highlands sustains the Nile River [4-9] and tends to peak in August with a northerly shift of the equatorial trough and meridional Hadley circulation. An easterly jet induced by Indian monsoon outflow spreads convection across the Sahel [10-14] depending on links between the Atlantic Walker circulation and Pacific Ocean heat anomalies [15-17].

National meteorological agencies tasked with short-term weather forecasts often use a nested mesoscale model such as Weather Research and Forecasting (WRF, [18]). However, model sensitivity to global initialization data and parameterization options $[19,20]$ are often untested, so forecasters must uncover bias in successive operational applications. To improve guidance, this research evaluates global and nested model ability to represent the Ethiopian atmospheric circulation, thermodynamic conditions, and convection during wet spells. Key features for consideration include the influx of tropical moisture, subtropical subsidence and heating, orographic and diurnal forcing, the thermal easterly jets, gradients in the meridional circulation, and rainfall intensity and location. In Section 2 the data and methods are outlined. Section 3 compares global model rainfall and its forcing in July-August, 2011, over northeast Africa and then focuses on a wet spell over the Ethiopian highlands. Nested model outcomes with two contrasting initialization schemes are evaluated, and conclusions are given in Section 4.

\section{Data and Methods}

Observational products used in this study include hourly $0.2^{\circ}$ Coupled Forecast System (CFS, [21]) NOAH-parameterized [22] data, 3-hourly $0.25^{\circ} \mathrm{cMorph}$ multisatellite estimates [23], daily $0.1^{\circ}$ African Rainfall Climatology observations (ARC2, [24]), monthly $0.5^{\circ}$ gauge observations interpolated by the Global Precipitation Climatology Center (GPCC, [25]), and monthly $0.5^{\circ}$ satellite estimates from the Tropical Rainfall 


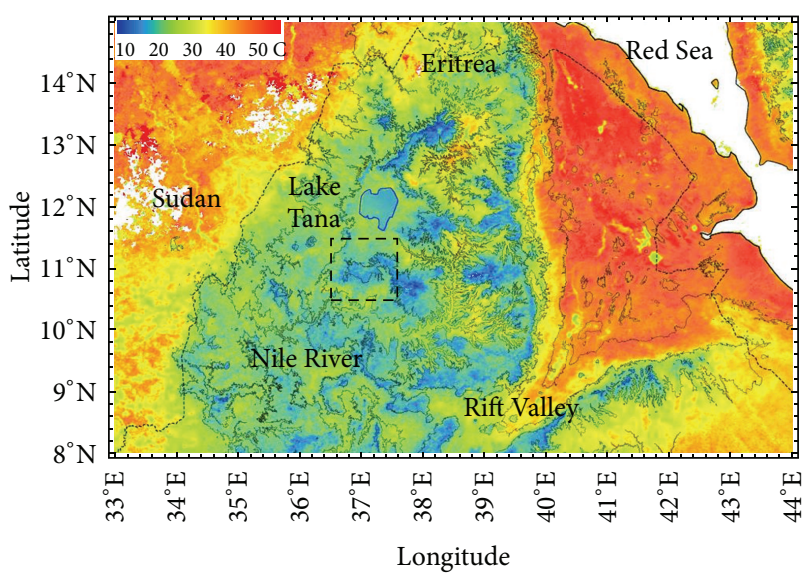

(a)

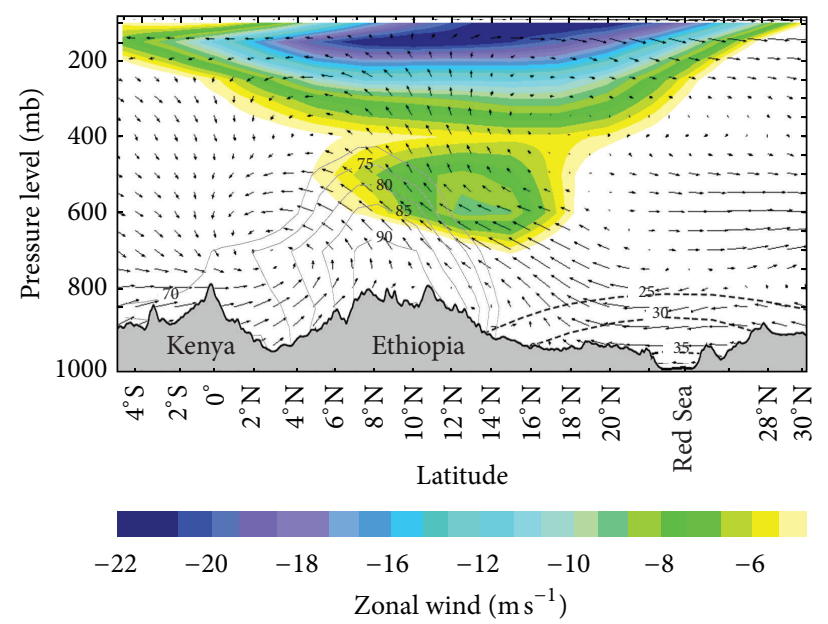

(b)

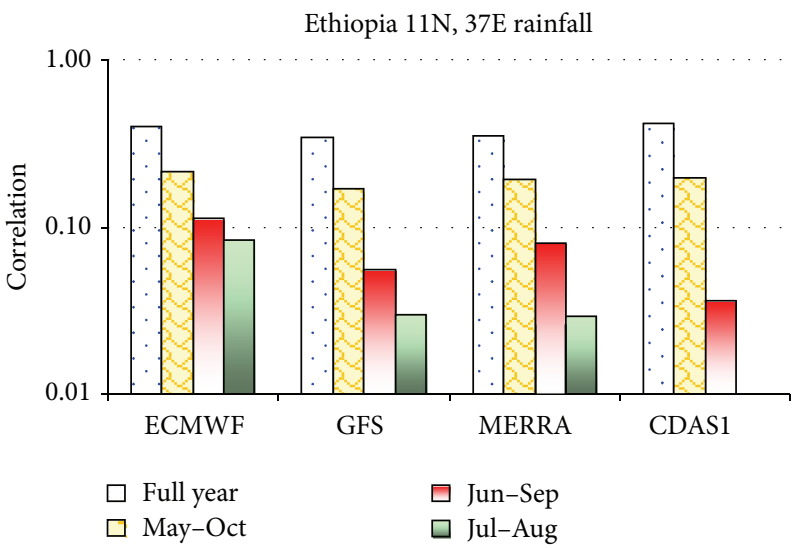

(c)

Figure 1: (a) MODIS land surface temperature 15 July-15 August, 2011, and elevation contours at 800 m intervals. (b) July-August, 2011, N-S section on $37^{\circ} \mathrm{E}$ of the circulation (meridional vertical VW vectors, $\max =5 \mathrm{~m} / \mathrm{s}$ ), zonal wind (shaded), relative humidity $>70 \%$ (contours), and temperature $>25^{\circ} \mathrm{C}$ (dashed) from NCEP2, with topographic profile. (c) Intercomparison of cross-correlations between model estimated daily rainfall and ARC2 observations 2000-2012, for a $1^{\circ}$ grid-cell (dashed in a), in diminishing seasons.

Monitoring Mission (TRMM). Our focus is a longitude slice and grid-cell in the Nile River catchment (Figure 1(a)). Ethiopian rainfall from various sources has been evaluated by Verdin et al. [26], Dinku et al. [27], and Jacob et al. [28]. Background data on surface temperature and vegetation fraction were analyzed from $1 \mathrm{~km}$ MODIS satellite [29]. Hourly surface evaporation and runoff were analyzed from the Global Land Data Assimilation System GLDAS [30].

The model fields for consideration are 3-hourly and daily $1^{\circ}$ Global Forecast System (GFS) analyses, $1^{\circ}$ European Community Medium-range Weather Forecasts interim reanalysis (ECMWF, [31]), $1^{\circ}$ NASA Modern Reanalysis (MERRA, [32, 33]), monthly $2^{\circ}$ National Center for Environmental Prediction reanalysis (NCEP2, [34]), and $2^{\circ}$ Climate Data Assimilation System (CDAS1) analyses. The variables employed are meridional and zonal winds at $850-200 \mathrm{mb}$ levels, vertical motion, relative humidity, surface skin and air temperature, latent heat flux, and evaporation and surface runoff. Runoff from the Ethiopia highlands has been studied [35, 36]; here, an area-average is considered.

The methodology used to evaluate model outputs progresses from broad to narrow, first considering July-August, 2000-2012, averages representative of mid-summer. Data are analyzed on a meridional section at $37^{\circ} \mathrm{E} \pm 1^{\circ}$ from $5^{\circ} \mathrm{S}-30^{\circ} \mathrm{N}$ (northeast Africa). Cross-correlations between model daily rainfall and observations are calculated over the highlands and for a Nile Valley grid-cell $\left(11^{\circ} \mathrm{N}, 37^{\circ} \mathrm{E}\right)$ in the period 2000-2012. The sample size is progressively reduced from all-year $(N=4748)$ to wet months $(N=806)$ to focus on model ability to represent daily rainfall timing and intensity. The erratic nature of rainfall provides $\sim 70$ degrees of freedom for continuous records and $\sim 250$ for wet months, so correlations $>0.1$ are significant at $90 \%$ confidence. Next, weather conditions in the Ethiopian highlands on 29 July, 2011, are analyzed from global fields and aircraft meteorological data relay (AMDAR) profiles. Twenty-four 


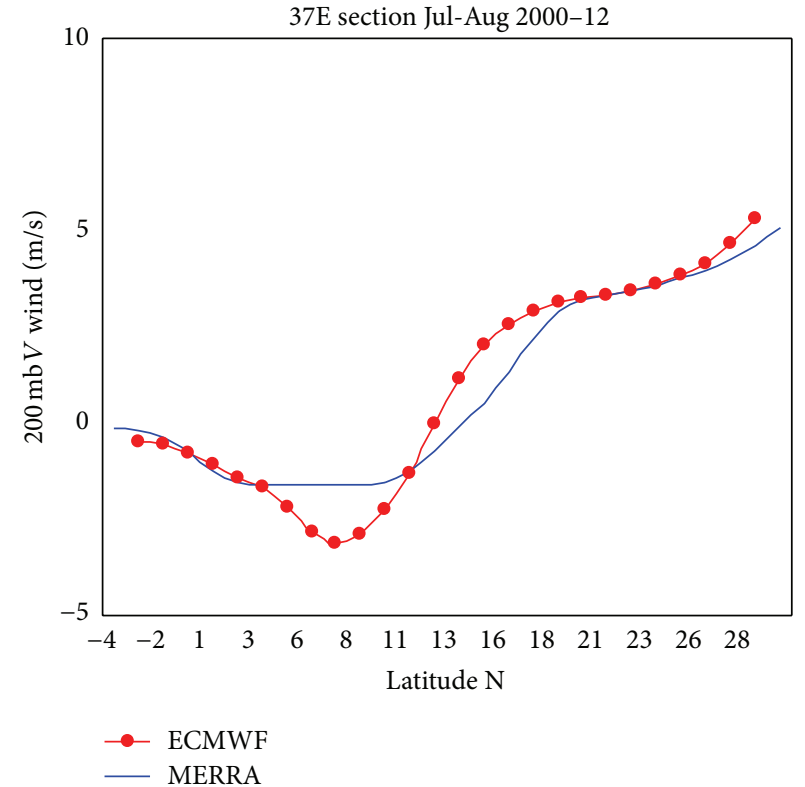

(a)

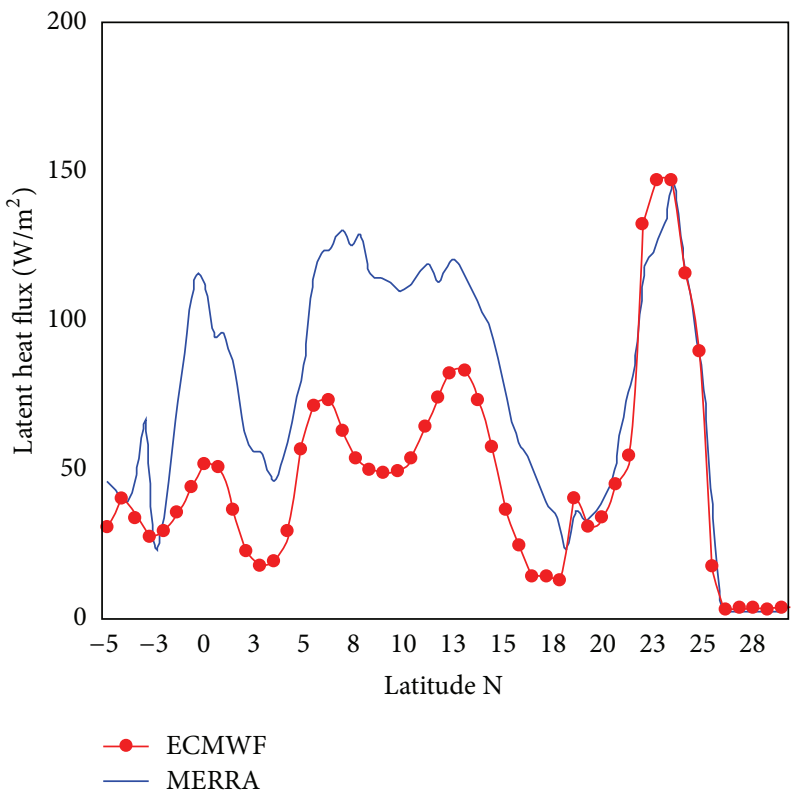

(c)

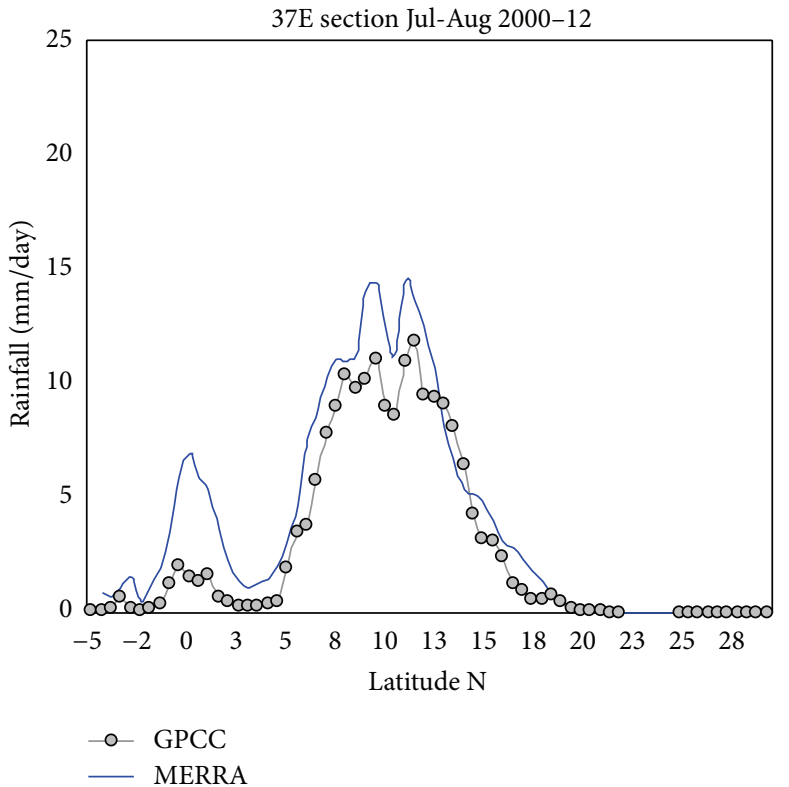

(b)

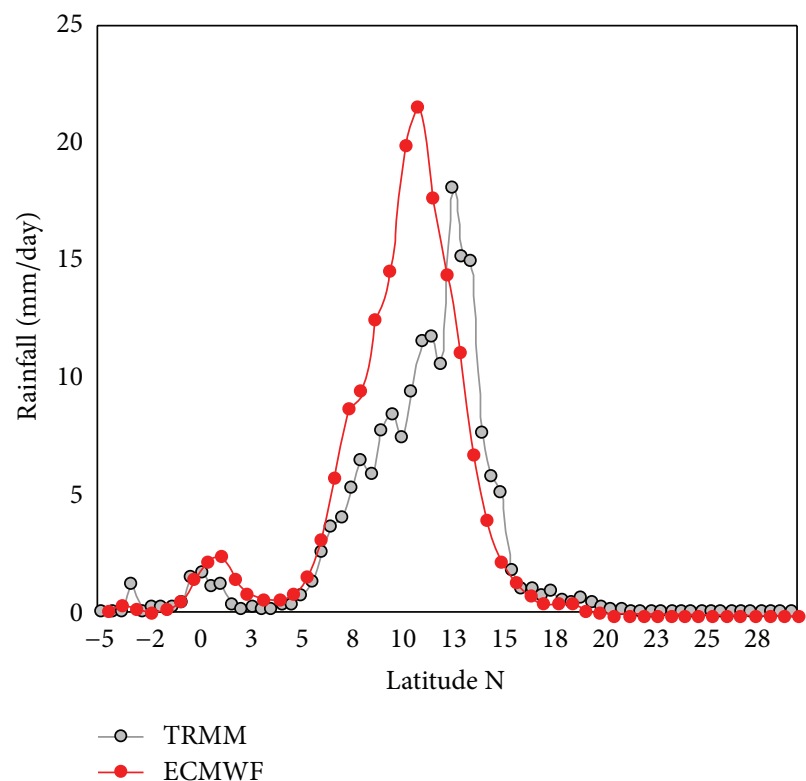

(d)

Figure 2: Mean July-August, 2000-2012, variables along N-S slice on $37^{\circ}$ E for ECMWF and MERRA models: (a) 200 mb meridional wind, (b, d) rainfall from model and GPCC/TRMM observations, and (c) model latent heat flux.

hour ensemble back-trajectories are calculated by the Hysplit model for an end-point at $11^{\circ} \mathrm{N}, 37^{\circ} \mathrm{E}, 1000$, and $3000 \mathrm{~m}$ above ground using GFS data. Lastly mesoscale model simulations are compared with Meteosat cloud top temperatures.

Nested model simulations of rainfall, radar reflectivity, and winds are performed using the nonhydrostatic WRF version 3.2.1. The model is configured with a horizontal grid of $3 \mathrm{~km}$ over the Ethiopian highlands; it has 90 vertical sigma levels from surface to $10 \mathrm{mb}$. The WRF options used are Lin microphysics, NOAH surface scheme, MYJ planetary boundary layer, BMJ cumulus parameterization, and RRTM atmospheric radiation. A $36-\mathrm{hr}$ simulation is conducted starting at 00:00 LST 29 July, 2011, to capture a full diurnal cycle. Two distinct runs are made: in the first the initial and time-dependent lateral boundary conditions are derived from GFS and in the second they are derived from ECMWF. Outputs at the time of peak rainfall (18:00-24:00 LST) are considered. 


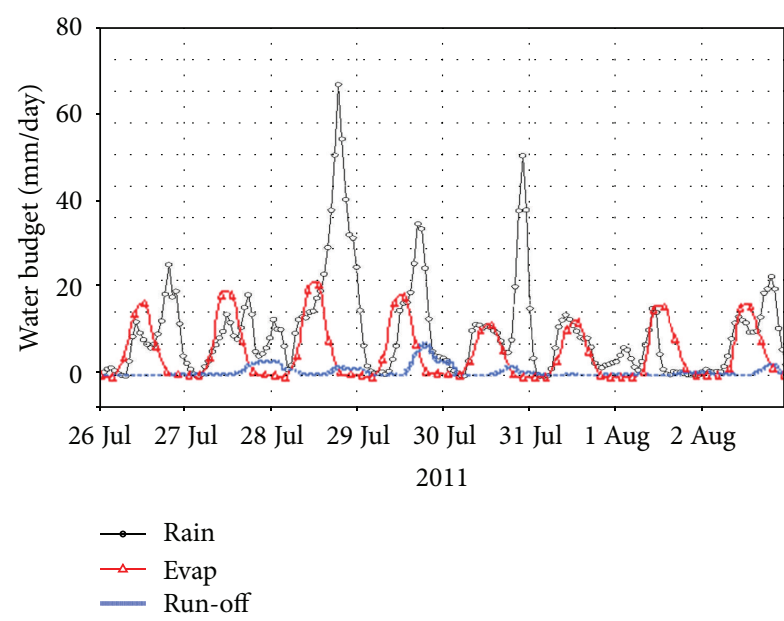

(a)

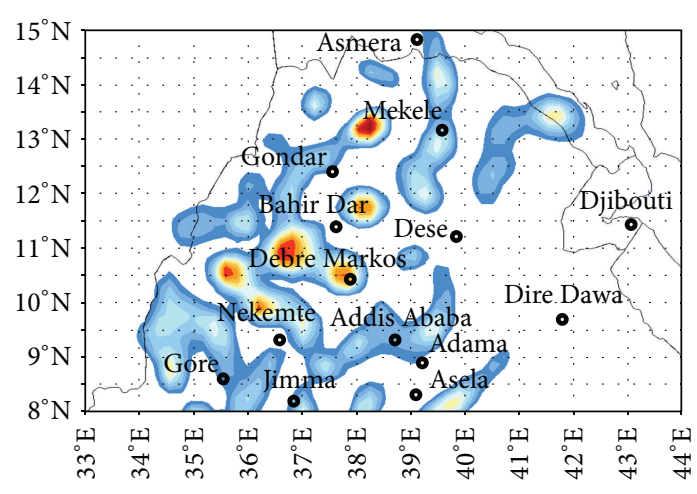

$0 \quad 5 \quad 10152025303540455055606570$

(b)

Figure 3: (a) CFS rainfall, evaporation, and runoff hourly time series for $1^{\circ}$ grid-cell centered on $11^{\circ} \mathrm{N}, 37^{\circ} \mathrm{E}$ in the period 26 July-2 August, 2011. (b) CFS mean rainfall map ( $\mathrm{mm} /$ day) on 29 July with urban centers.

\section{Results}

3.1. Background and Seasonal Features. The Ethiopian highlands are cool during summer with land surface temperatures $<20^{\circ} \mathrm{C}$ at elevations above $1600 \mathrm{~m}$ (Figure 1(a)). West of the escarpment at $39^{\circ} \mathrm{E}$ AIRS satellite-derived clouds exceed $50 \%$ coverage in July-August, 2011. In the surrounding lowlands, day-time land surface temperatures exceed $50^{\circ} \mathrm{C}$ and heat fluxes lift the boundary layer $>1 \mathrm{~km}$. The diurnal heating pattern resembles a warm ring surrounding a $5^{\circ} \times 5^{\circ}$ cool center; consequently, highland thunderstorms build towards sunset.

Key features of the large-scale seasonal environment in July-August, 2011, are illustrated in Figure 1(b) by N-S section on $37^{\circ} \mathrm{E}$. Easterly jets are seen in the $600 \mathrm{mb}$ and $150 \mathrm{mb}$ layers over the northern highlands $8-16^{\circ} \mathrm{N}$. Relative humidity exceeds $80 \%$ in a dome up to $500 \mathrm{mb}$ over the southern highlands $4-12^{\circ} \mathrm{N}$, according to NCEP2 data. A warm surface layer $>25^{\circ} \mathrm{C}$ in the latitudes $16-30^{\circ} \mathrm{N}$ lies beneath the northern Hadley circulation that tilts over the northern highlands. The southern Hadley circulation is reflected in meridional overturning above the Turkana Valley $\left(2-4^{\circ} \mathrm{N}\right)$. The two Hadley cells create deep ascent over Ethiopia that is enhanced by cyclonic vorticity near the easterly jets (Figure 1(b)).

Our aim here is to evaluate model simulated rainfall over the highlands. In Figure 1(c) daily analyses for the $11^{\circ} \mathrm{N}$, $37^{\circ} \mathrm{E}$ grid-cell are cross-correlated with ARC2 observations in the period 2000-2012. Considering the whole year, models achieve significant cross-correlations $(>0.35)$ and thus capture the annual cycle, the dry season, and minor rain events. Standard deviations are ARC2 $4.8 \mathrm{~mm}$ /day, GPCC 5.9, GFS 7.8, and ECMWF 11.3. As the season is narrowed, eliminating the annual cycle and no-rain days, the correlations decline (as degrees of freedom increases). With a July-August window, the ECMWF reanalysis obtains a daily cross-correlation > 0.1 (Figure 1(c)), while GFS, MERRA, and CDAS1 are near zero. These findings are consistent with Bosilovich et al.
[37], wherein the Taylor diagram of African seasonal rainfall puts ECMWF closer to observation than other reanalyses. This raises three questions. Why do the global models perform differently? Are discrepancies due to assimilation or parameterization? How will the performance of nested mesoscale models be affected by initialization source? The answers to these questions could improve short-range flood forecasts.

To understand why models produce different local rainfall, comparisons are made along the $37^{\circ} \mathrm{E}$ longitude slice averaged for July-August 2000-2012. This macro perspective is useful to diagnose key features in MERRA and ECMWF outputs [38]. The models exhibit similarities in $850 \mathrm{mb}$ meridional winds and $500 \mathrm{mb}$ zonal winds (not shown). Significant differences are found in the upper meridional winds and rainfall (Figures 2(a), 2(b), and 2(d)). The ECMWF model has a sharper $d V_{200} / d y$ gradient with $\min / \max$ at $6^{\circ} \mathrm{N} / 15^{\circ} \mathrm{N}$, while the MERRA model has a weaker gradient and $\mathrm{min} / \mathrm{max}$ at $2^{\circ} \mathrm{N} / 18^{\circ} \mathrm{N}$. The weaker gradient coincides with a broader band of seasonal rain in MERRA with peaks on $0^{\circ} \mathrm{N}, 9^{\circ} \mathrm{N}$, and $13^{\circ} \mathrm{N}$ in accord with GPCC observations. In contrast, ECMWF simulates a single zone of heavy rain at $10^{\circ} \mathrm{N}$ that is close to TRMM estimates (cf. [39]). Latent heat fluxes also show differences (Figure 2(c)), with MERRA transpiration double ECMWF over the highlands. Yet both exhibit a U-shape suggesting that winds penetrate the edges but not the densely vegetated interior $\left(9^{\circ} \mathrm{N}\right)$. The two models have similar latent heat fluxes over the Red Sea $\left(23-24^{\circ} \mathrm{N}\right)$ and exhibit a high/low pattern over the equator/Turkana Valley. The feedback between surface transpiration and convection is known to affect model performance [40].

3.2. Wet Spell Characteristics. Given our interest in shortterm flood forecasts, attention is turned to a case of heavy rainfall in the last week of July 2011. Time series of CFS rainfall and GLDAS evaporation and runoff are given in Figure 3(a) 


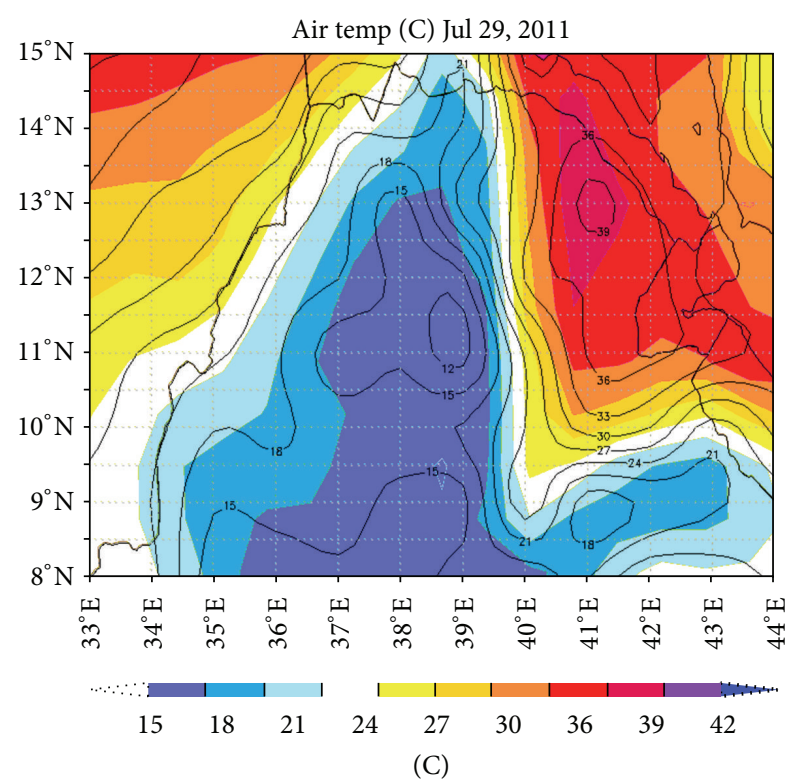

(a)

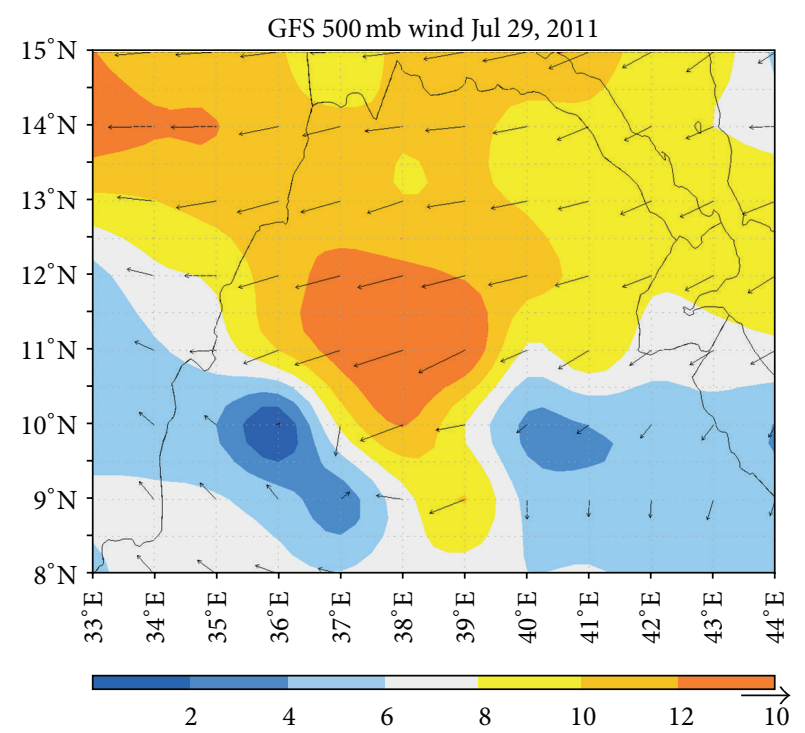

(b)

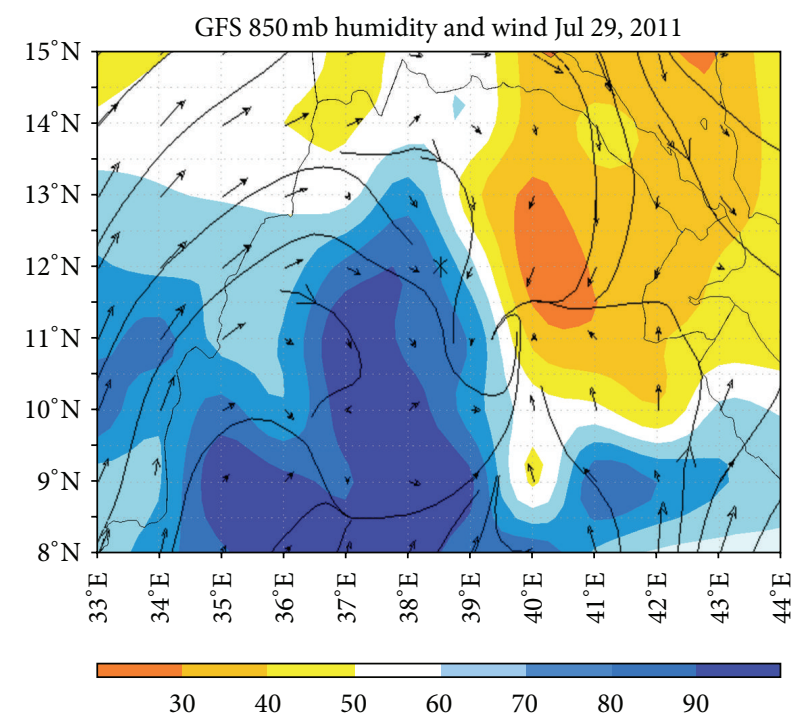

(c)

FIGURE 4: Regional weather features on 29 July, 2011: (a) surface air temperature (GFS contoured, ECMWF shaded), (b) GFS 500 mb wind (speed shaded), and (c) GFS $850 \mathrm{mb}$ relative humidity (shaded), and $850 \mathrm{mb}$ wind vectors ( $\mathrm{max}=12 \mathrm{~m} / \mathrm{s}$ ) and streamlines.

for the $11^{\circ} \mathrm{N}, 37^{\circ} \mathrm{E}$ grid-cell. Evaporation followed the diurnal cycle of solar radiation peaking at $\sim 16 \mathrm{~mm} /$ day, while rainfall fluctuated up to $\sim 40 \mathrm{~mm} /$ day around sunset (cf. [41, 42]). GLDAS runoff was $<10 \%$ of rainfall (cf. $[43,44]$ ) and was highest on the 29th. The map of CFS rainfall on 29 July, 2011, (Figure 3(b)) reveals widespread values $>5 \mathrm{~mm}$ and isolated areas $>50 \mathrm{~mm}$ between $10-13^{\circ} \mathrm{N}$ and $36-38^{\circ} \mathrm{E}$. This wet spell spawned a number of squall lines that moved westward across the Sahel, causing heavy rains at N'Djamena and eventually consolidating off Dakar into an African easterly wave that passed through the Caribbean.

A synoptic weather analysis for 29 July, 2011, is provided in Figure 4. The GFS and ECMWF models are consistent in their representation of surface temperature. A tongue of cold air extends along $38^{\circ} \mathrm{E}$ (Figure $4(\mathrm{a})$ ) where elevation exceeds $2000 \mathrm{~m}$. The GFS $500 \mathrm{mb}$ winds were easterly $>10 \mathrm{~m} / \mathrm{s}$ north of $10^{\circ} \mathrm{N}$ (Figure 4(b)). GFS $850 \mathrm{mb}$ relative humidity exhibited a gradient between a dry cell in the northeast and a moist zone in the southwest (Figure 4(c)). $850 \mathrm{mb}$ winds were southwesterly over Sudan, rotated to north-westerly over Eritrea and in the dry zone, and wrapped into a vortex at $11^{\circ} \mathrm{N}, 39^{\circ} \mathrm{E}$.

Three AMDAR aircraft profiles (Figure 5) highlight wind shear on the evening of 29 July, 2011. Winds below $3200 \mathrm{~m}$ $(\sim 700 \mathrm{mb})$ were light $(5 \mathrm{~m} / \mathrm{s})$ and from the south-west at Addis Ababa and from north-west at Asmera. There was a weak temperature inversion at $3000 \mathrm{~m}$ (725 mb) at Asmera, 


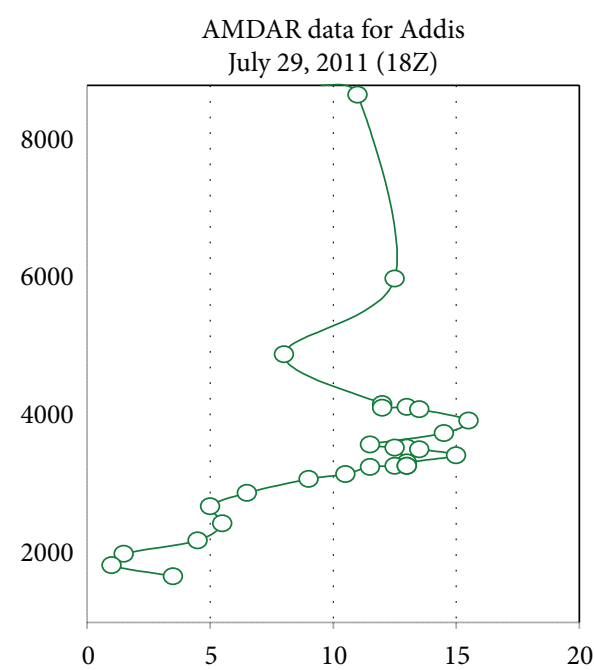

(a)

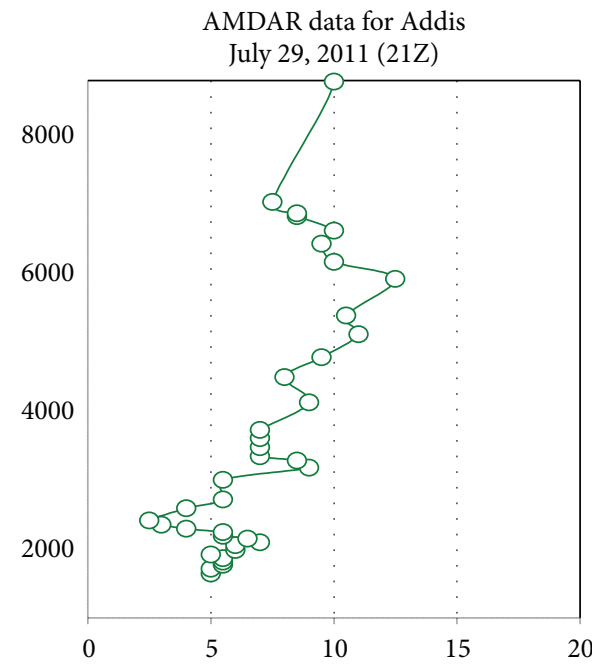

(c)

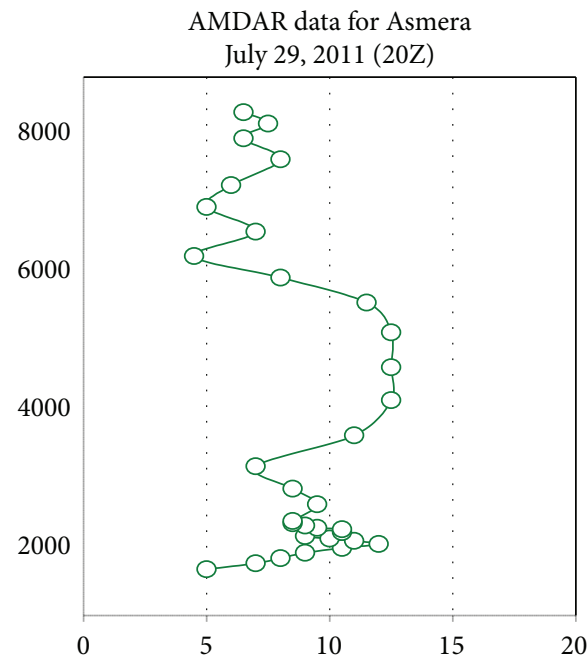

$-\infty$ spd

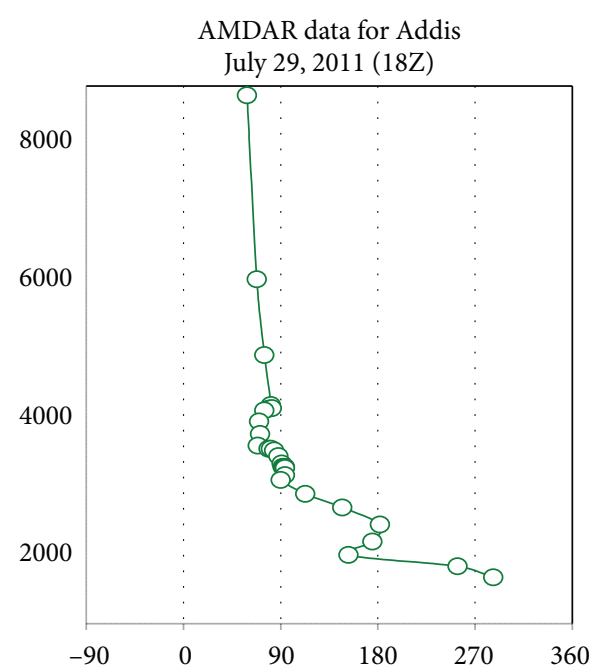

(b)

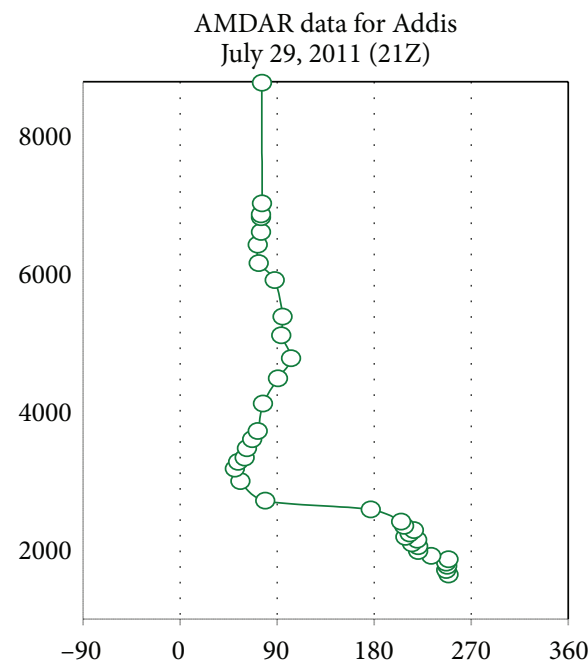

(d)

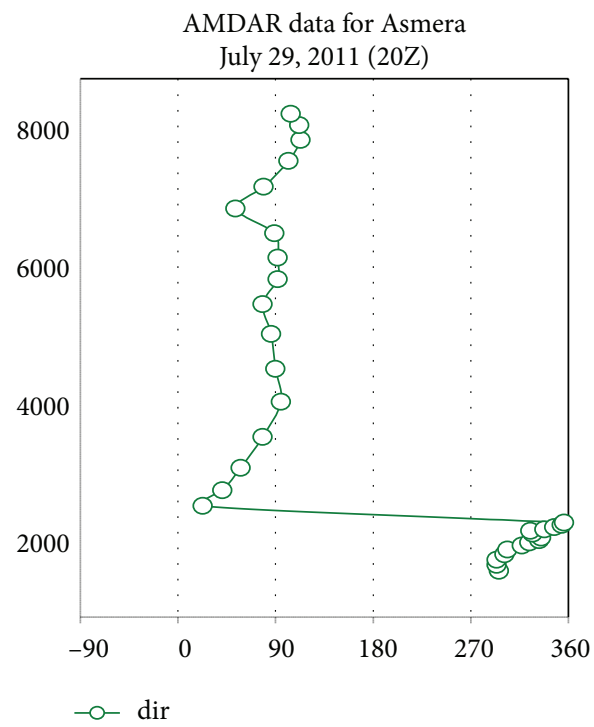

(f)

FIGURE 5: AMDAR aircraft wind profiles for evening of 29 July, 2011 (height $-\mathrm{m}$, speed $-\mathrm{m} / \mathrm{s}$ ). 


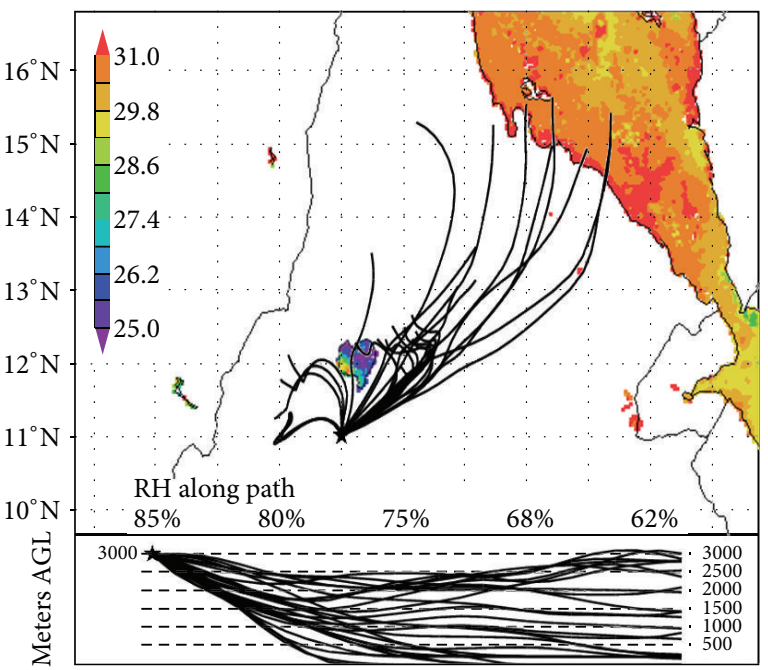

(a)

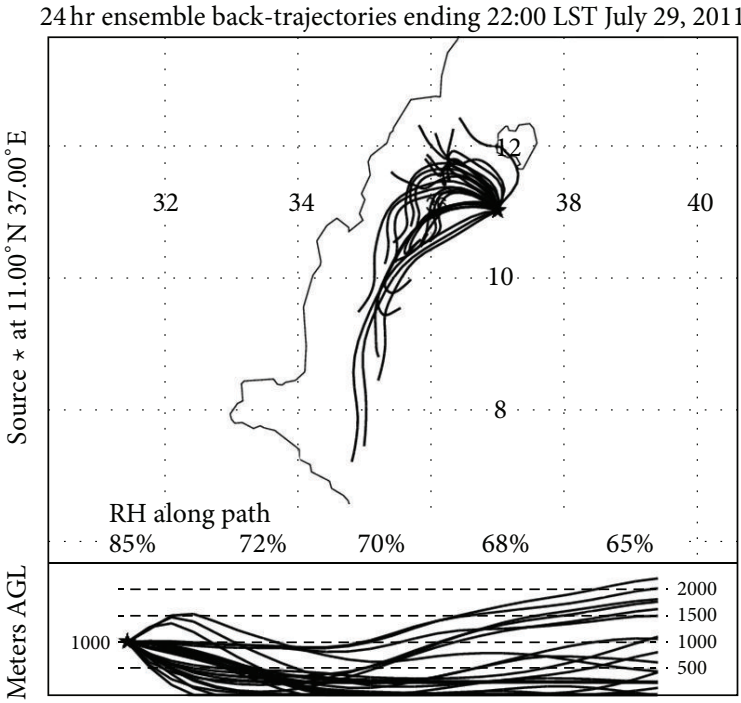

(c)

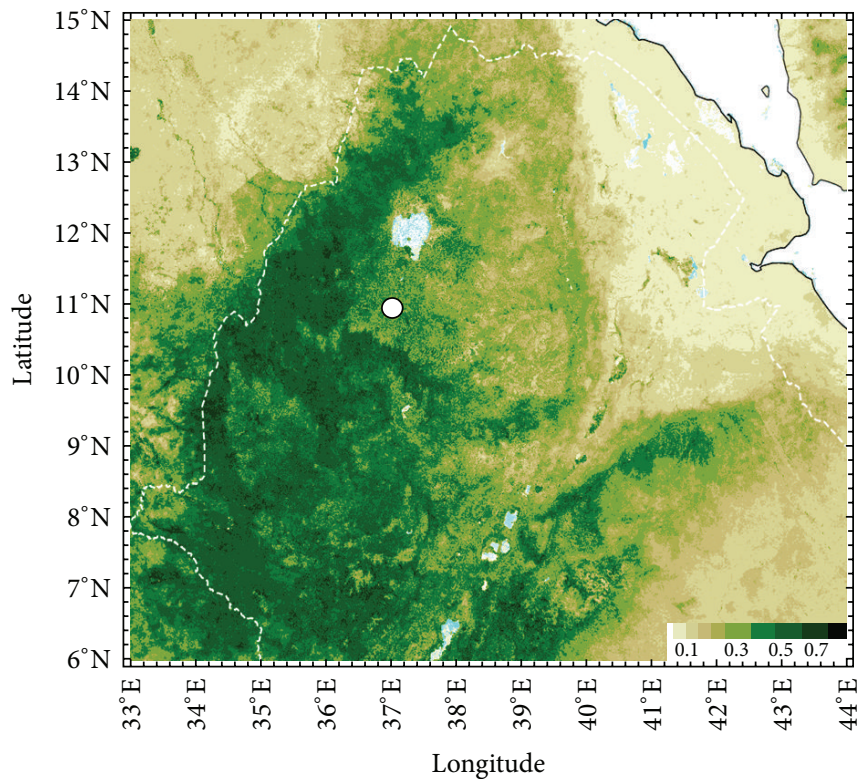

(b)
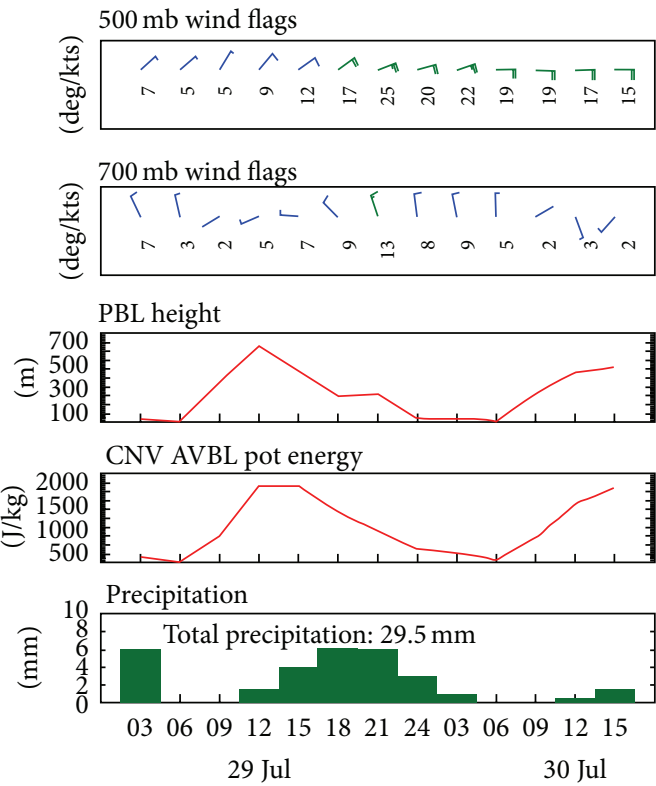

(d)

FIGURE 6: $24 \mathrm{hr}$ ensemble back trajectories ending at $11^{\circ} \mathrm{N}, 37^{\circ} \mathrm{E}$ at 22:00 LST 29 July, 2011: (a) for $3000 \mathrm{~m}$ above ground with SST, (b) MODIS vegetation fraction during the period, (c) trajectories ending $1000 \mathrm{~m}$ above ground, and (d) GFS meteogram of winds, PBL height, CAPE, and rainfall at $3-\mathrm{hr}$ intervals at $11^{\circ} \mathrm{N}, 37^{\circ} \mathrm{E}$. Map scales vary; GFS relative humidity along (vertical section) path is given in (a, c).

above which winds rotated to easterly. An easterly jet of $15 \mathrm{~m} / \mathrm{s}$ was observed in the 5000-6000 $\mathrm{m}$ layer $(\sim 500 \mathrm{mb})$ in all three profiles. A key feature of the AMDAR profiles at Addis Ababa was the prevalence of surface layer south-westerly flow and an absence of northerly winds. The temperature lapse rate was $-6.8^{\circ} \mathrm{C} / \mathrm{km}$ and thus conditionally unstable.

Twenty-four hour back-trajectories for an endpoint at $11^{\circ} \mathrm{N}, 37^{\circ} \mathrm{E}, 1000 \mathrm{~m}$, and $3000 \mathrm{~m}$ above ground are illustrated in Figures 6(a) and 6(c) in plan and section view. The $3000 \mathrm{~m}$ ensemble trajectories (based on GFS data) converged from Eritrea between the Red Sea (SST $\sim 30^{\circ} \mathrm{C}$ ) and Lake Tana $\left(25^{\circ} \mathrm{C}\right)$ and exhibited a rising component. Along-path relative humidity increased from $62 \%$ to $85 \%$. The $1000 \mathrm{~m}$ ensemble trajectories converged from the southwest where the underlying vegetation fraction exceeds 0.5 (Figure 6(b)). Back-trajectories at both levels exhibited clockwise, anticyclonic curvature. The GFS meteogram for the grid-cell (Figure 6(d)) highlights diurnal fluctuations: winds increased in the evening, following peaks in the boundary layer height (700 $\mathrm{m}$ at 12:00) and convective available potential energy 


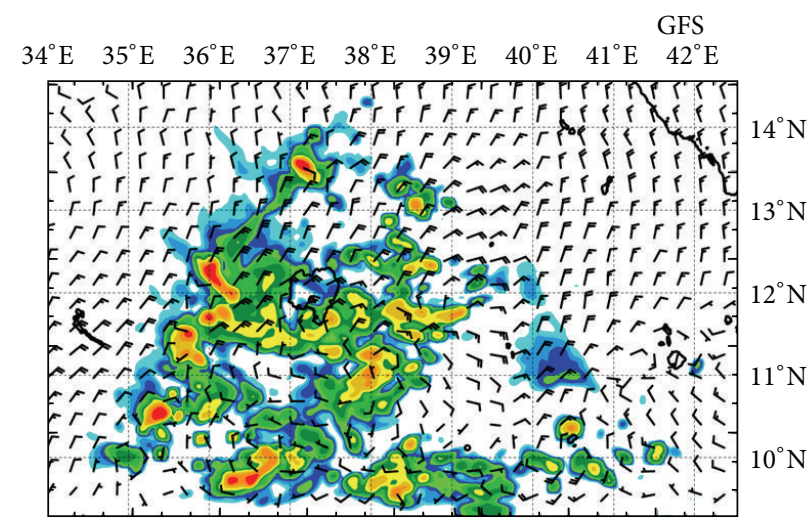

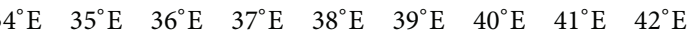

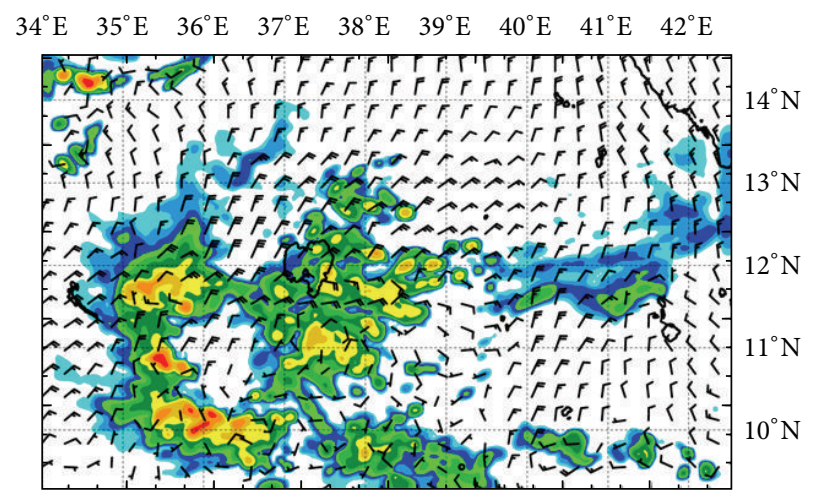

ECMWF

$34^{\circ} \mathrm{E} \quad 35^{\circ} \mathrm{E} \quad 36^{\circ} \mathrm{E} \quad 37^{\circ} \mathrm{E} \quad 38^{\circ} \mathrm{E} \quad 39^{\circ} \mathrm{E} \quad 40^{\circ} \mathrm{E} \quad 41^{\circ} \mathrm{E} \quad 42^{\circ} \mathrm{E}$

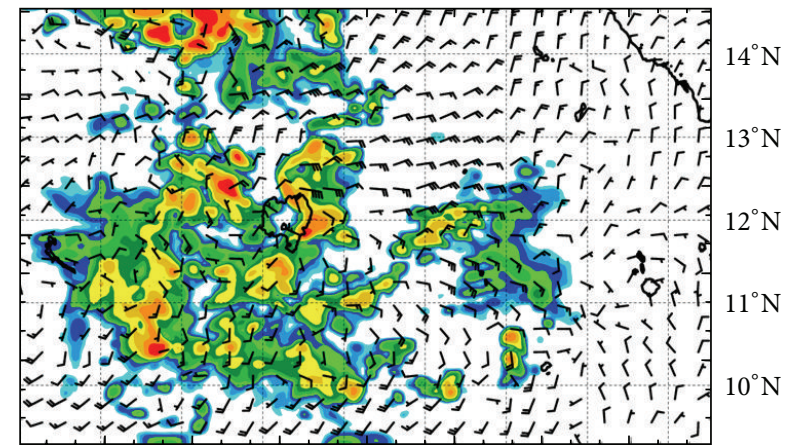

(a)

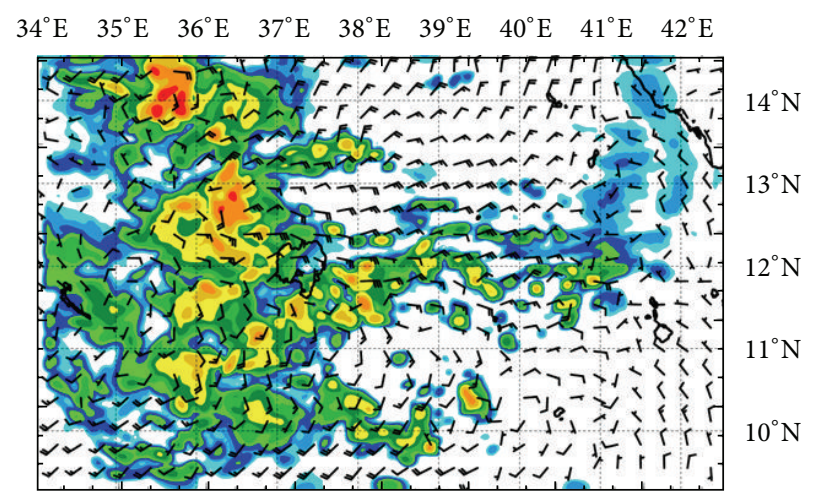

(b)

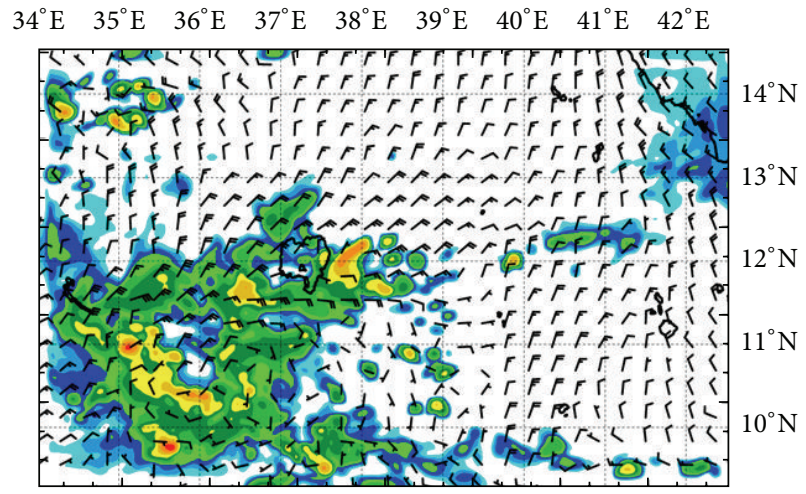

$\begin{array}{lllllllllllllllll}5 & 10 & 15 & 20 & 25 & 30 & 35 & 40 & 45 & 50 & 55 & 60 & 65 & 70 & 75\end{array}$

(dBZ)

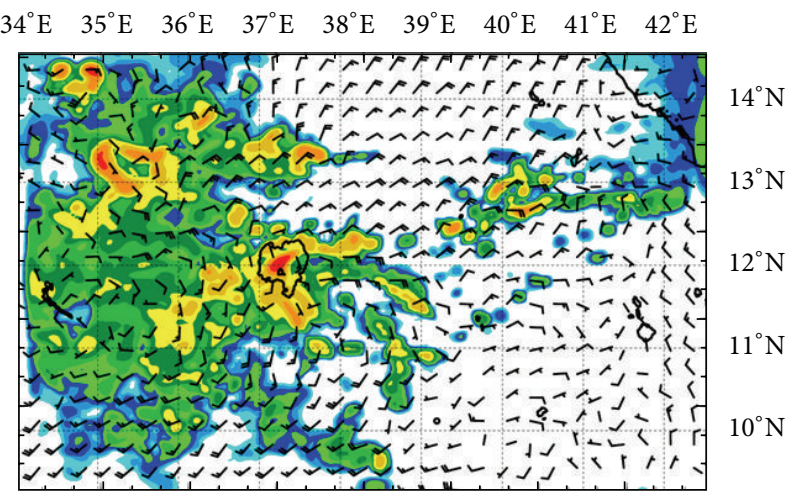

$\begin{array}{lllllllllllllll}5 & 10 & 15 & 20 & 25 & 30 & 35 & 40 & 45 & 50 & 55 & 60 & 65 & 70 & 75\end{array}$

(dBZ)

(c)

FIGURE 7: High resolution WRF simulated radar reflectivity and $700 \mathrm{mb}$ wind with GFS initialization (left) and ECMWF (right) for 29 July, 2011: (a) 20:00 LST, (b) 22:00 LST, and (c) 24:00 LST.

(2000 J/kg at 15:00). The diurnal peak of rainfall was 18:0024:00 LST, totaling $\sim 30 \mathrm{~mm}$. A key finding is that the GFS model emphasizes the surface northerly winds observed at Asmera.

3.3. WRF Model Simulation. The WRF model simulation of the 29 July, 2011, convective outbreak, with contrasting GFS and ECMWF initialization, is presented in Figures 7(a)-7(f). It offers a snapshot assessment of how the two models handled afternoon to evening thunderstorm development. The ECMWF-WRF simulated radar reflectivity was widespread in the north, while winds were easterly to the east and southerly to the south. The GFS-WRF simulation located the thunderstorms further south in response to stronger 


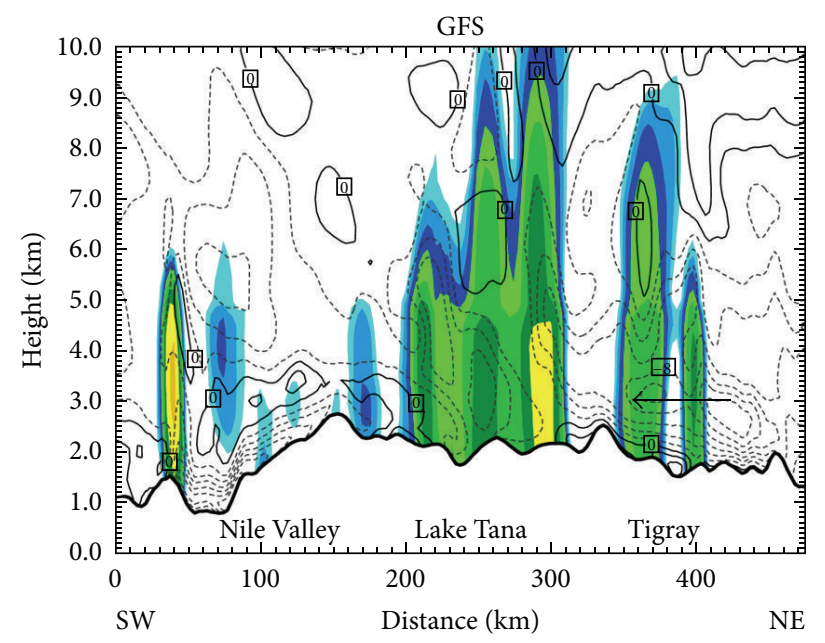

(a)

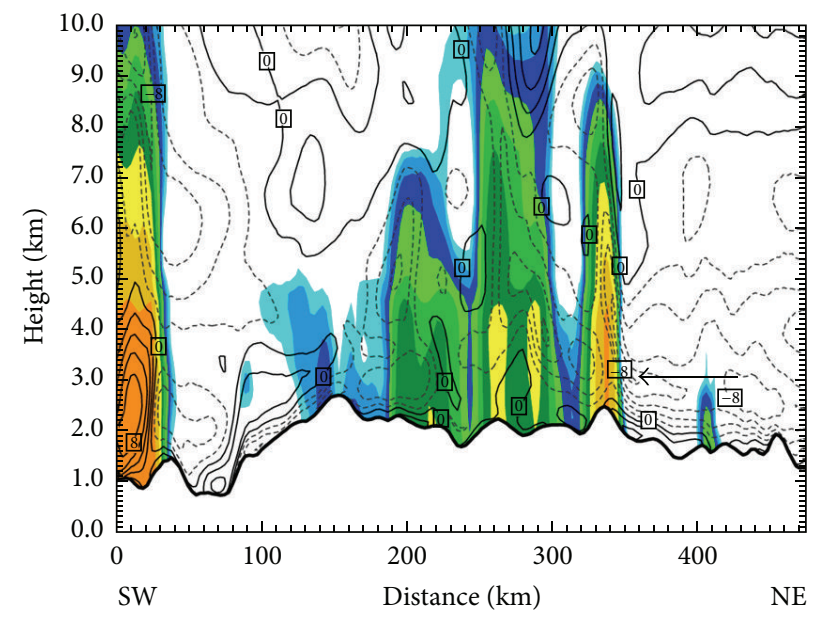

(c)

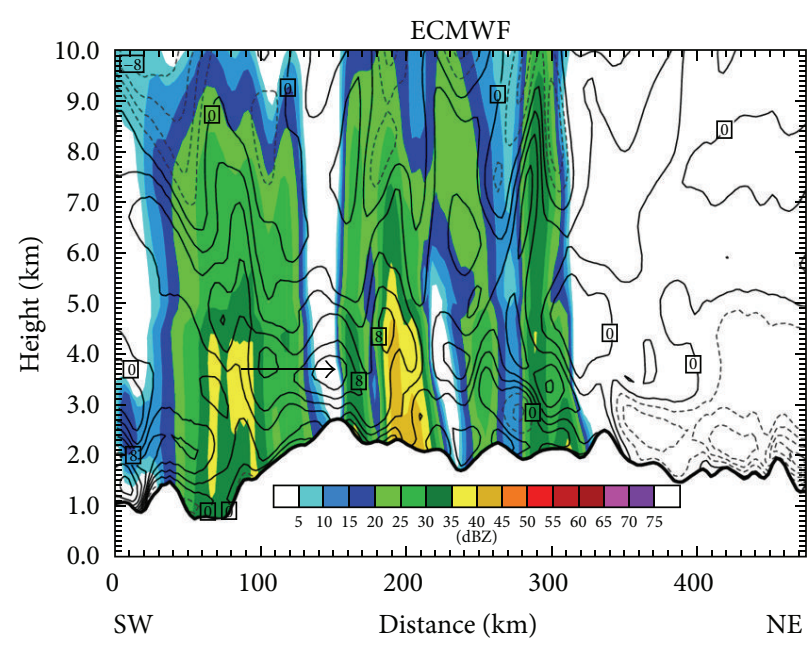

(b)

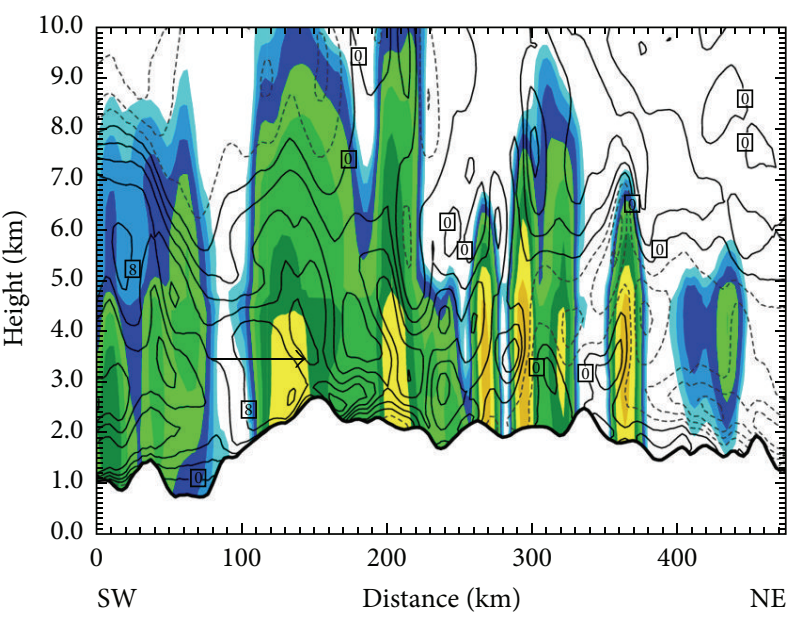

(d)

FIGURE 8: High resolution WRF simulated vertical NE-SW section (cf. Figure 9(a)) of meridional (V) wind (contour interval 2 m/s, dashed southward) and radar reflectivity (shaded according to scale upper right) at (a) 20:00 LST and (b) 22:00 LST; initialization with GFS (left) and ECMWF (right). Arrows highlight contrasting meridional flow.

northerly flow at $700 \mathrm{mb}$. The thunderstorms aggregated more in the ECMWF-WRF simulation, while the GFS-WRF simulation had isolated cells, for example, $10-11^{\circ} \mathrm{N}, 36-37^{\circ} \mathrm{E}$.

A vertical NE-SW section analysis of these simulations (Figures 8(a)-8(d)) reveals weaker convection in the GFSWRF run associated with northerly flow over the northern highlands $(V<-8 \mathrm{~m} / \mathrm{s}$ at $3 \mathrm{~km})$. While the ECMWF-WRF simulation spread convection into the Nile Valley, the GFSWRF estimated radar reflectivity was more isolated. The ECMWF-WRF run had southerly flow over the southern highlands $(V>+8 \mathrm{~m} / \mathrm{s}$ to $5 \mathrm{~km})$. Hence, the WRF simulation reveals a stronger southern (northern) Hadley cell when initialized with ECMWF (GFS) data in this case. Together with the earlier seasonal analysis of meridional winds (cf. Figure 2(a)), there is a reason why the ECMWF better represents the timing and intensity of daily rainfall.

Rainfall maps at 18:00, 20:00, and 22:00 LST from the two simulations are given in Figures 9(a) and 9(b) in comparison with Meteosat cloud top temperatures (Figure 9(c)). The GFS-WRF simulation had westward propagating cells that separated into two meridional squall lines. The ECMWFWRF simulation had rainfall further north in meridional bands that aggregated with time, in qualitative agreement with the Meteosat images. While this case has highlighted key differences, a greater sample of nested runs would be needed to make a conclusive argument.

\section{Conclusions}

An intercomparison of global model estimates of daily rainfall over the Ethiopian highlands, 2000-2012, determined that ECMWF was closer to ARC2 observations than other models. This was related to the ECMWF representation of seasonal rainfall as a narrow band $>15 \mathrm{~mm} /$ day on $10^{\circ} \mathrm{N}$ colocated with a stronger meridional overturning Hadley 
GFS

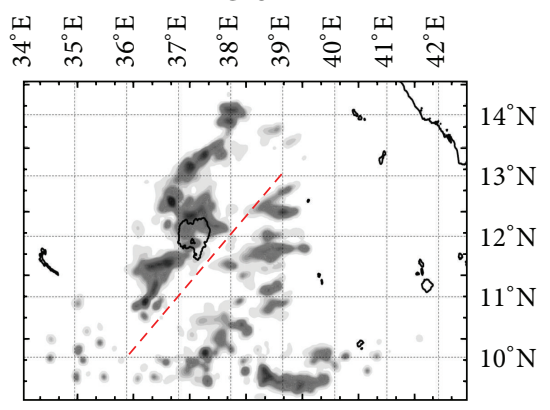

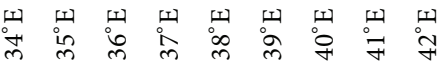

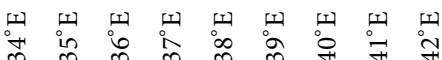

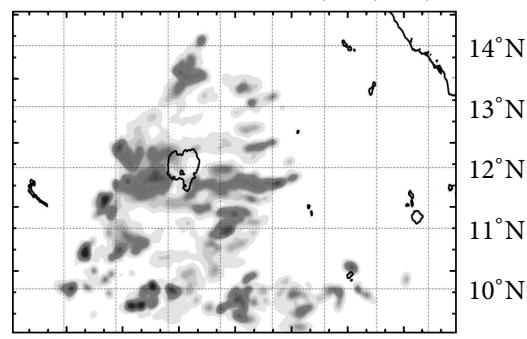

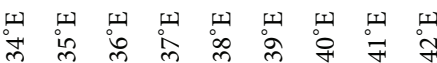

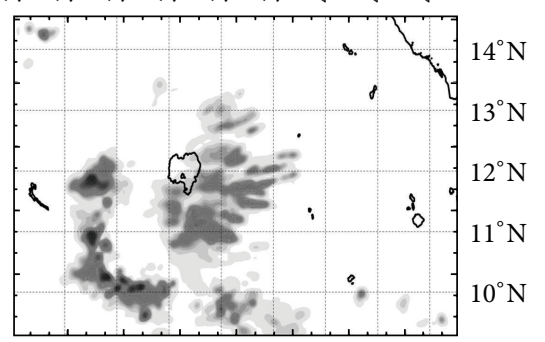

ECMWF

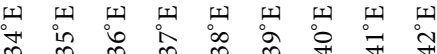

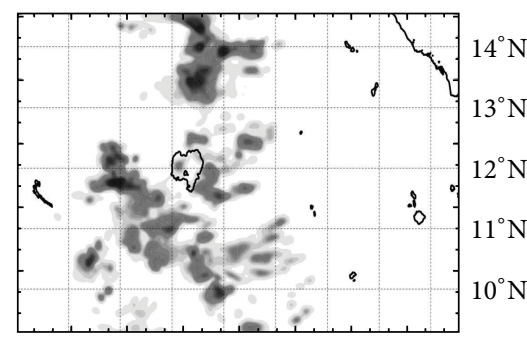

(a)

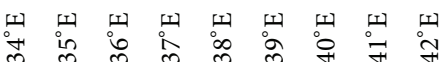

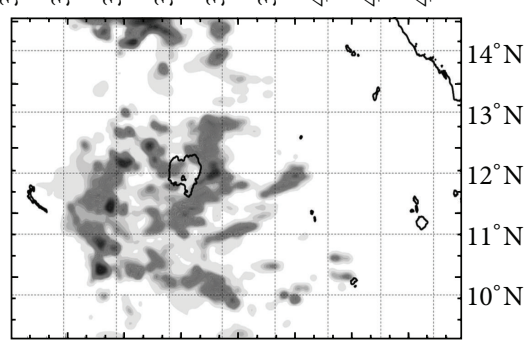

(b)

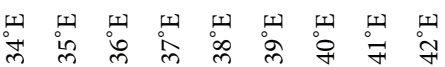

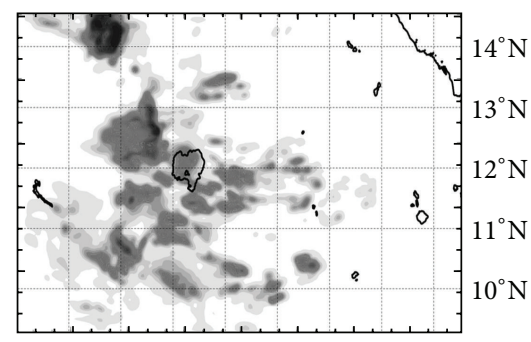

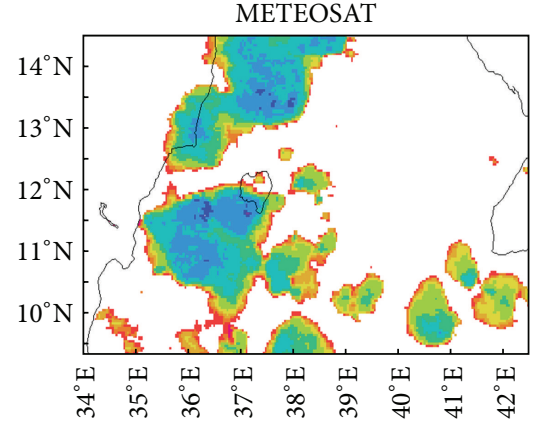

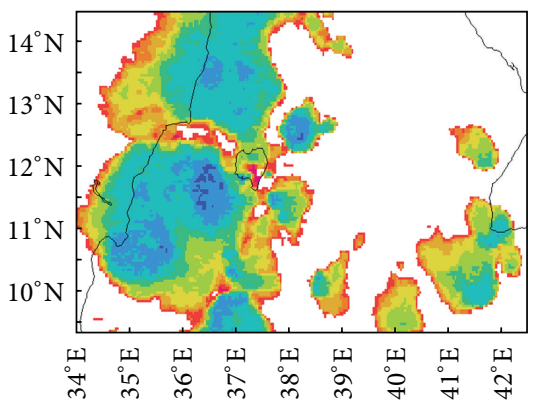

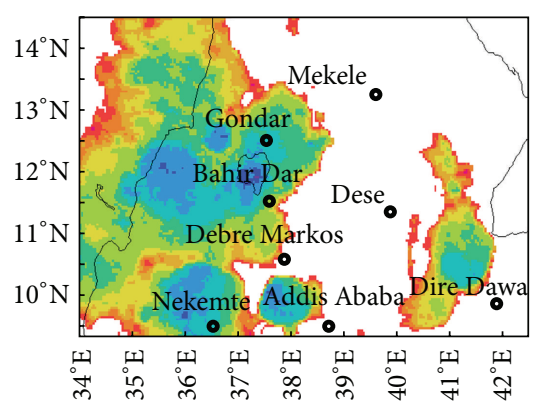

$-90-85-80-75-70-65-60-55-50-45-40$

(C)

(c)

FIGURE 9: WRF simulated rainfall on 29 July for (a) 18:00, (b) 20:00, and (c) 22:00 LST, with max shading = 75 mm/day. GFS initialization (left), ECMWF (middle), and comparison with Meteosat IR images (right). Red dashed line in (a, left) is Figure 8 section.

circulation. The contrasting background states influence a nested WRF model simulation of heavy rains in the upper Nile Valley on 29 July, 2011. The GFS (ECMWF) initialization yields stronger northerly (southerly) $700 \mathrm{mb}$ winds over northern (southern) Ethiopia. AMDAR profiles during the wet spell exhibit south-westerly winds below $700 \mathrm{mb}$ and an easterly jet aloft. The surface inflow passes across the densely vegetated southwestern highlands, suggesting latent heat flux parameterization as a source of contrast that deserves further attention.

Back-trajectories moving up from the southwest make a "left hook" around the cool plateau, sweeping across the border of Sudan and Eritrea, before curling into a thunderstorm cluster on 29 July, 2011. Part of the southerly flow over Kenya is entrained into the vortex, but most passes into the Arabian Sea. The stronger southern Hadley penetration onto 
the Ethiopian highlands by the ECMWF-WRF simulation is suggested to improve its representation of rainfall. The GFSWRF simulation, in contrast, maintains a stronger northern Hadley circulation that would bring subtropical air to the highlands, inhibiting moist convection.

Further progress in mesoscale forecasting of Ethiopian wet spells will depend on better operational access to both local observations and ECMWF initialization fields. The addition of humidity to AMDAR aircraft profiles should contribute to more accurate short-term forecasts. While our case study has highlighted key differences in GFS/ECMWF inputs and WRF model outcomes, a more quantitative assessment of a larger sample of wet spell simulations is needed to better understand Hadley cell interaction with the easterly jets and diurnal convection over the Ethiopian highlands.

\section{Conflict of Interests}

The authors declare that there is no conflict of interests regarding the publication of this paper.

\section{Acknowledgments}

Data and analyses were drawn from the websites: IRI Climate Library, NOMADS-NCEP, NOAA-Ready-ARL, NASAGiovanni, NOAA-AMDAR, and Climate Explorer KNMI. This work is supported by the Rockefeller Foundation, the Ethiopian Institute for Agriculture Research, and National Science Foundation Grants nos. AGS-0855286 and AGS1209296.

\section{References}

[1] L. Olsson, L. Eklundh, and J. Ardö, "A recent greening of the Sahel-trends, patterns and potential causes," Journal of Arid Environments, vol. 63, no. 3, pp. 556-566, 2005.

[2] O. Amogu, L. Descroix, K. S. Yéro et al., "Increasing river flows in the Sahel?” Water, vol. 2, pp. 170-199, 2010.

[3] M. R. Jury, "A return to wet conditions over Africa: 1995-2010," Theoretical and Applied Climatology, vol. 111, pp. 471-481, 2013.

[4] E. Vowinckel and S. Orvig, "The water budget and potential water reserves of the East Africa source region of the Nile," Journal of Applied Meteorology, vol. 18, pp. 148-155, 1979.

[5] M. D. Dettinger and H. F. Diaz, "Global characteristics of stream flow seasonality and variability," Journal of Hydrometeorology, vol. 1, no. 4, pp. 289-310, 2000.

[6] Y. Seleshi and P. Camberlin, "Recent changes in dry spell and extreme rainfall events in Ethiopia," Theoretical and Applied Climatology, vol. 83, no. 1-4, pp. 181-191, 2006.

[7] A. Ahmed and U. Ismail, "Sediment in the Nile River system," UNESCO-IHP Report, 2008.

[8] D. Conway, A. Pereschino, S. Ardoin-Bardin, H. Hamandawana, C. Dieulin, and G. Mahé, "Rainfall and water resources variability in sub-Saharan Africa during the twentieth century," Journal of Hydrometeorology, vol. 10, no. 1, pp. 41-59, 2009.

[9] M. R. Jury, "Meteorological scenario of Ethiopian floods in 2006-2007," Theoretical and Applied Climatology, vol. 104, no. 1-2, pp. 209-219, 2011.
[10] M. Hulme and N. Tosdevin, "The Tropical easterly Jet and Sudan rainfall: a review," Theoretical and Applied Climatology, vol. 39, no. 4, pp. 179-187, 1989.

[11] P. Camberlin, "Rainfall anomalies in the source region of the Nile and their connection with the Indian summer monsoon," Journal of Climate, vol. 10, no. 6, pp. 1380-1392, 1997.

[12] J. W. Wegiel and C. G. Herbster, "The origin of African easterly waves," in Proceedings of the 16th Conference Weather Analysis and Forecasting, American Meteorological Society, Phoenix, Ariz, USA, 1998.

[13] C. M. Hill and Y.-L. Lin, "Initiation of a mesoscale convective complex over the Ethiopian Highlands preceding the genesis of Hurricane Alberto (2000)," Geophysical Research Letters, vol. 30, no. 5, pp. 36-1, 2003.

[14] C. Potter, P. Zhang, S. Klooster, V. Genovese, S. Shekhar, and V. Kumar, "Understanding controls on historical river discharge in the world's largest drainage basins," Earth Interactions, vol. 8, pp. 1-21, 2004.

[15] D. Korecha and A. G. Barnston, "Predictability of JuneSeptember rainfall in Ethiopia," Monthly Weather Review, vol. 135, no. 2, pp. 628-650, 2007.

[16] A. Yeshanew and M. R. Jury, "North African climate variability. Part 2: tropical circulation systems," Theoretical and Applied Climatology, vol. 89, no. 1-2, pp. 37-49, 2007.

[17] Z. T. Segele, P. J. Lamb, and L. M. Leslie, "Seasonal-tointerannual variability of Ethiopia/horn of Africa monsoon. Part I: associations of wavelet-filtered large-scale atmospheric circulation and global sea surface temperature," Journal of Climate, vol. 22, no. 12, pp. 3396-3421, 2009.

[18] W. C. Skamarock, J. B. Klemp, J. Dudhia et al., "A description of the advanced research WRF version 2," Tech. Rep. NCAR/TN468+STR, 2005

[19] W. A. Gallus Jr. and J. F. Bresch, "Comparison of impacts of WRF dynamic core, physics package, and initial conditions on warm season rainfall forecasts," Monthly Weather Review, vol. 134, no. 9, pp. 2632-2641, 2006.

[20] S. A. Michelson and J.-W. Bao, "Sensitivity of low-level winds simulated by the WRF model in California's Central Valley to uncertainties in the large-scale forcing and soil initialization," Journal of Applied Meteorology and Climatology, vol. 47, no. 12, pp. 3131-3149, 2008.

[21] S. Saha, S. Moorthi, H. -L. Pan et al., "The NCEP climate forecast system reanalysis," Bulletin of the American Meteorological Society, vol. 91, pp. 1015-1057, 2010.

[22] M. B. Ek, K. E. Mitchell, Y. Lin et al., "Implementation of Noah land surface model advances in the National Centers for Environmental Prediction operational mesoscale Eta model," Journal of Geophysical Research D, vol. 108, no. 22, pp. 1-16, 2003.

[23] R. J. Joyce, J. E. Janowiak, P. A. Arkin, and P. P. Xie, "cMorph: a method that produces global precipitation estimates from passive microwave and infrared data at high spatial and temporal resolution," Journal of Hydrometeorology, vol. 5, pp. 487-503, 2004.

[24] N. S. Novella and W. M. Thiaw, "African rainfall climatology version 2 for famine early warning systems," Journal of Applied Meteorology and Climatology, vol. 52, no. 3, pp. 588-606, 2013.

[25] B. Rudolf, A. Becker, U. Schneider, A. Meyer-Christoffer, and M. Ziese, "The new GPCC Full Data Reanalysis Version 5, providing high-quality gridded monthly precipitation data for the global land-surface Global Precipitation Climatology Centre," Tech. Rep., 2010, http://gpcc.dwd.de. 
[26] J. Verdin, C. Funk, G. Senay, and R. Choularton, "Climate science and famine early warning," Philosophical Transactions of the Royal Society B, vol. 360, no. 1463, pp. 2155-2168, 2005.

[27] T. Dinku, P. Ceccato, K. Cressman, and S. J. Connor, "Evaluating detection skills of satellite rainfall estimates over desert locust recession regions," Journal of Applied Meteorology and Climatology, vol. 49, no. 6, pp. 1322-1332, 2010.

[28] M. Jacob, A. Frankl, Mitiku Haile, A. Zwertvaegher, and J. Nyssen, "Assessing spatio-temporal rainfall variability in a tropical mountain area (Ethiopia) using NOAA Rainfall Estimates," International Journal of Remote Sensing, vol. 34, pp. 8305-8321, 2013.

[29] G. Leptoukh, I. Csiszar, P. Romanov, S. Shen, T. Loboda, and I. Gerasimov, "NASA NEESPI data and services center for satellite remote sensing information," Environmental Research Letters, vol. 2, no. 4, Article ID 045009, 2007.

[30] M. Rodell, P. R. Houser, U. Jambor et al., "The Global Land data assimilation system," Bulletin of the American Meteorological Society, vol. 85, no. 3, pp. 381-394, 2004.

[31] D. P. Dee, S. M. Uppala, A. J. Simmons et al., "The ERA-Interim reanalysis: configuration and performance of the data assimilation system," Quarterly Journal of the Royal Meteorological Society, vol. 137, no. 656, pp. 553-597, 2011.

[32] M. Bosilovich, NASA's Modern Era Retrospective Analysis for Research and Applications: Integrating Earth observations, Earthzine, 2008.

[33] M. M. Rienecker, M. J. Suarez, R. Gelaro et al., "MERRA: NASA's modern-era retrospective analysis for research and applications," Journal of Climate, vol. 24, no. 14, pp. 3624-3648, 2011.

[34] M. Kanamitsu, W. Ebisuzaki, J. Woollen et al., "NCEP-DOE AMIP-II reanalysis (R-2)," Bulletin of the American Meteorological Society, vol. 83, no. 11, pp. 1631-1559, 2002.

[35] K. Descheemaeker, J. Nyssen, J. Poesen et al., "Runoff on slopes with restoring vegetation: a case study from the Tigray highlands, Ethiopia," Journal of Hydrology, vol. 331, no. 1-2, pp. 219-241, 2006.

[36] A. Frankl, M. Jacob, Mitiku Haile, J. Poesen, J. Deckers, and J. Nyssen, "The effect of rainfall on the spatio-temporal variability of cropping systems and duration of the crop cover in the Northern Ethiopian Highlands," Soil Use and Management, vol. 29, pp. 374-383, 2013.

[37] M. G. Bosilovich, J. Chen, F. R. Robertson, and R. F. Adler, "Evaluation of global precipitation in reanalyses," Journal of Applied Meteorology and Climatology, vol. 47, no. 9, pp. 22792299, 2008.

[38] S. Hastenrath, D. Polzin, and C. Mutai, "Circulation mechanisms of kenya rainfall anomalies," Journal of Climate, vol. 24, no. 2, pp. 404-412, 2011.

[39] T. Dinku, S. J. Connor, P. Ceccato, and C. F. Ropelewski, "Comparison of global gridded precipitation products over a mountainous region of Africa," International Journal of Climatology, vol. 28, no. 12, pp. 1627-1638, 2008.

[40] H. Douville, F. Chauvin, and H. Broqua, "Influence of soil moisture on the Asian and African monsoons. Part I: mean monsoon and daily precipitation," Journal of Climate, vol. 14, no. 11, pp. 2381-2403, 2001.

[41] J. Krauer, Rainfall, Erosivity \& Isoerodent Map of Ethiopia, vol. 15 of Soil Conservation Research Project, Research Report, University of Berne, Bern, Switzerland, 1988.
[42] J. Nyssen, H. Vandenreyken, J. Poesen et al., "Rainfall erosivity and variability in the Northern Ethiopian Highlands," Journal of Hydrology, vol. 311, no. 1-4, pp. 172-187, 2005.

[43] J. Nyssen, J. Poesen, J. Moeyersons, J. Deckers, M. Haile, and A. Lang, "Human impact on the environment in the Ethiopian and Eritrean highlands-a state of the art," Earth-Science Reviews, vol. 64, no. 3-4, pp. 273-320, 2004.

[44] M. Vanmaercke, A. Zenebe, J. Poesen, J. Nyssen, G. Verstraeten, and J. Deckers, "Sediment dynamics and the role of flash floods in sediment export from medium-sized catchments: a case study from the semi-arid tropical highlands in northern Ethiopia," Journal of Soils and Sediments, vol. 10, no. 4, pp. 611627, 2010. 

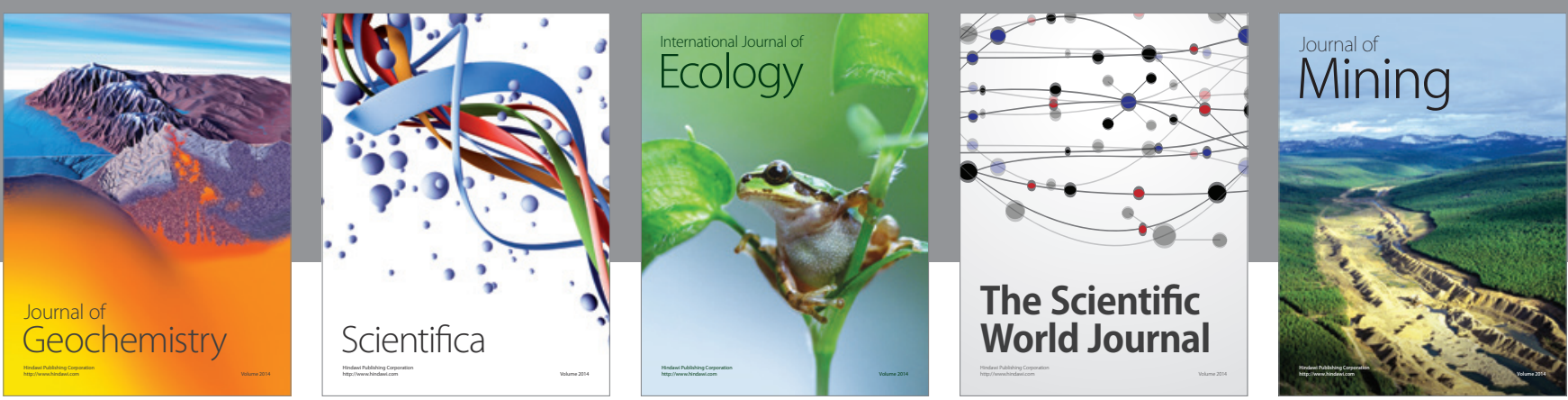

The Scientific World Journal
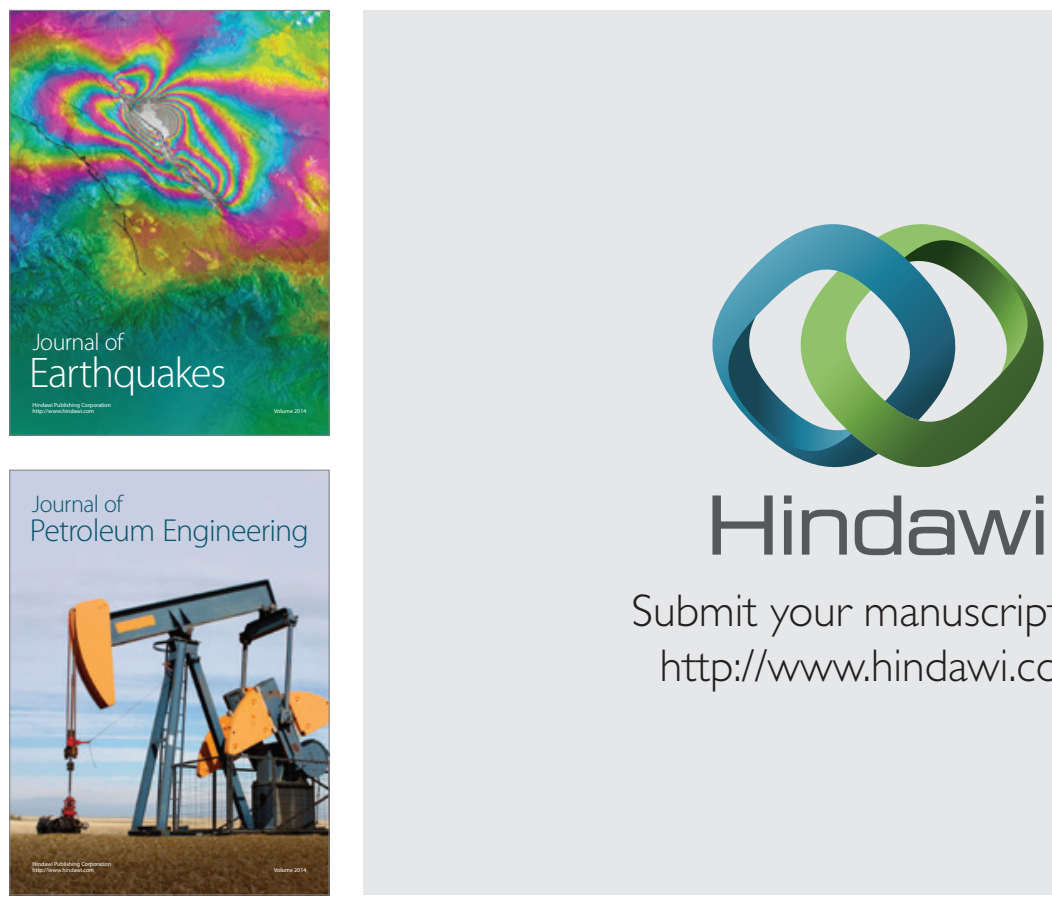

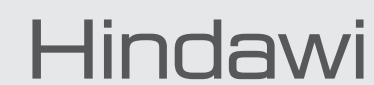

Submit your manuscripts at

http://www.hindawi.com
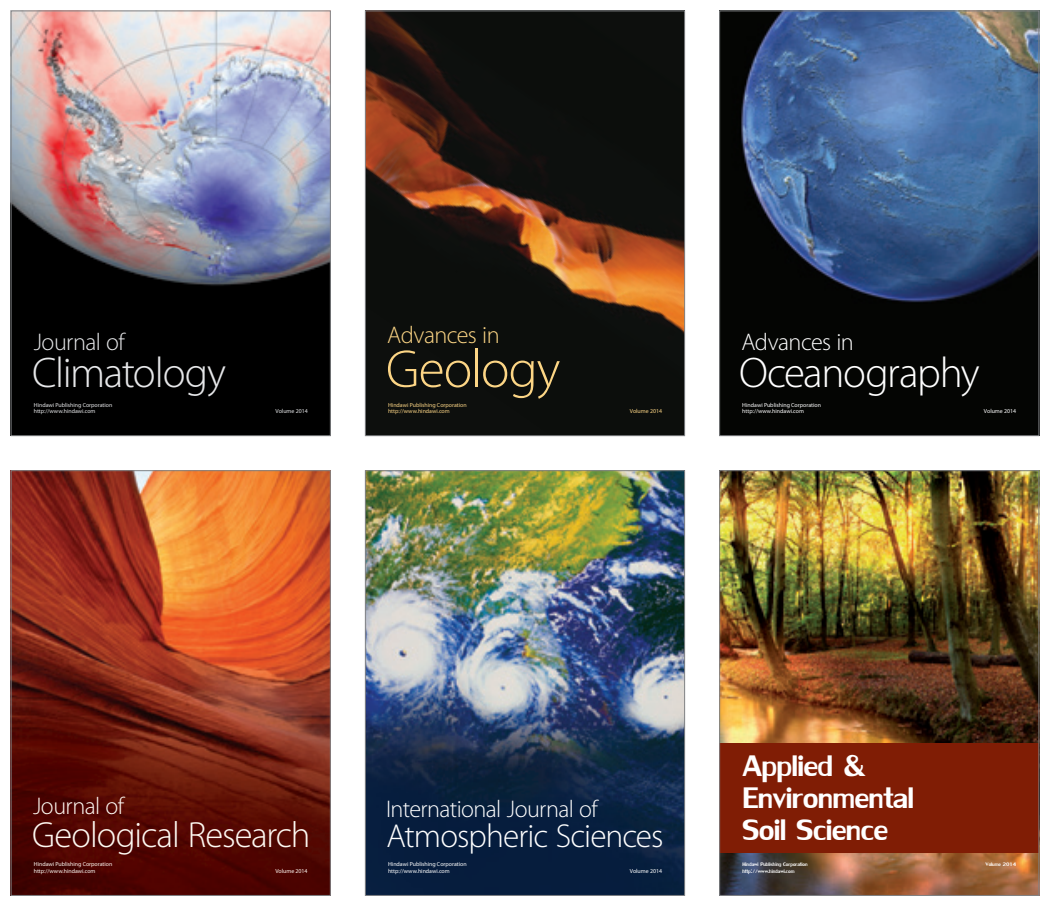
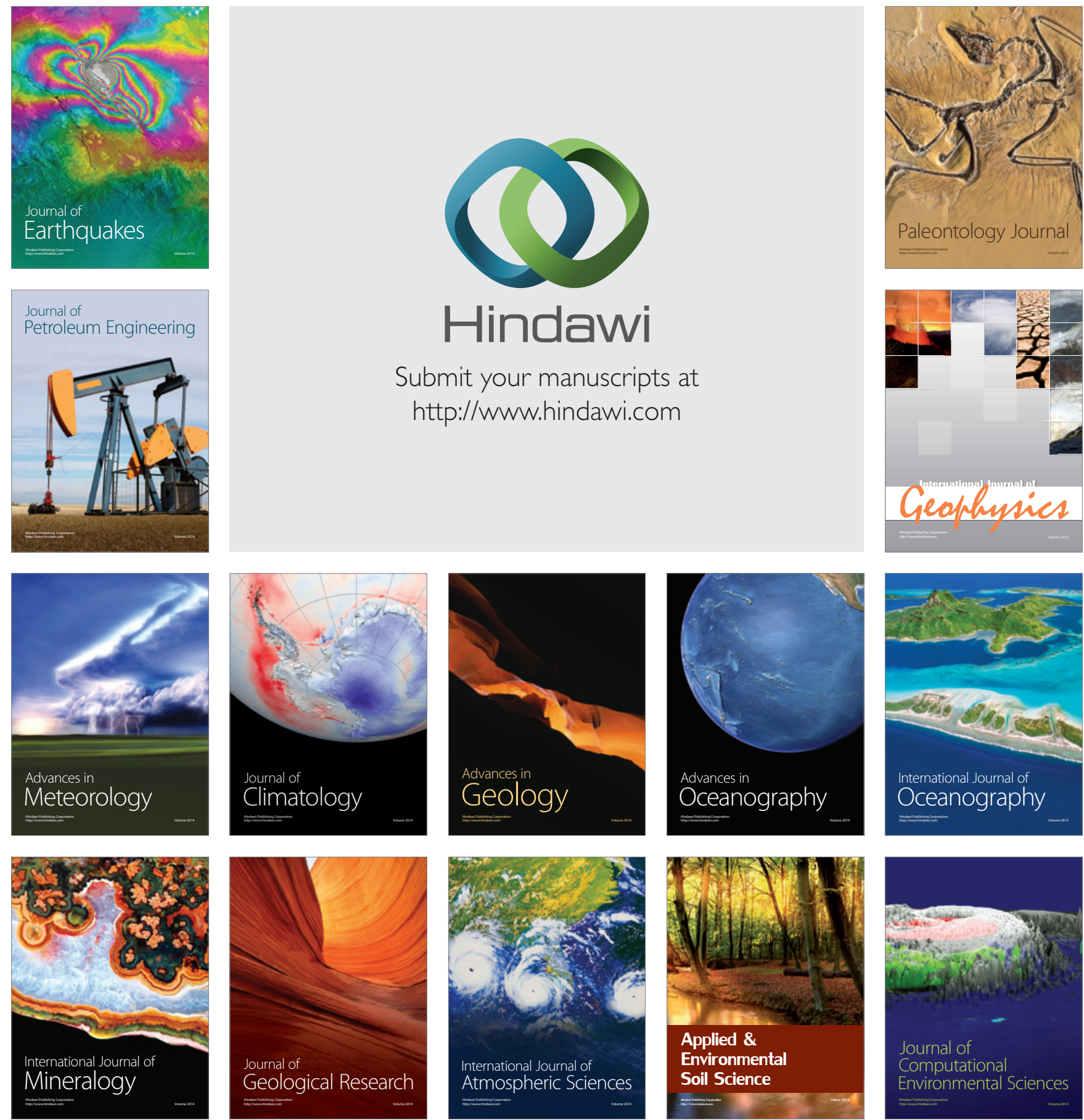